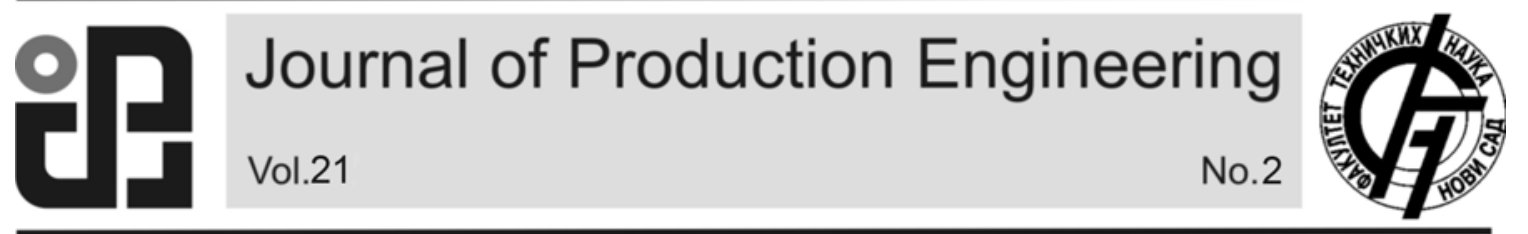

JPE (2018) Vol.21 (2)

Radović, A., Jović, S.

Original Scientific Paper

\title{
POWER COEFFICIENT PREDICTION OF TIDAL TURBINE BY ADAPTIVE SOFT COMPUTING METHODOLOGY
}

Received: 11 September 2018 / Accepted: 25 November 2018

\begin{abstract}
The main aim of the study was to analyze power coefficient of tidal turbine. The analzying was performed based on input-output data pairs. To arrange the data pairs measurements were performed on the tidal turebine. Adaptive soft computing methdology was used for estimation of relationship between the data pairs. The soft computing methodoogz was afterwards used for prediction of the power coefficient of tidal turbine based on the learined knowledge about the data pairs. During measurement procedure three inputs and one output were considered. The inputs are tip speed ratio - TSR, swap area of the turbine and time step. The output is power coefficient. The soft computing approach, namely, adaptive neuro fuzzz inference system - ANFIS was used for prediction of the power coefficient. Finally obtained results were compared with classical neural networks.
\end{abstract}

Key words: tidal turbine, power coefficient, soft computing, prediction

Predikcija koeficijenta snage plimskih turbina primenom adaptivne metdologije mekog računanja. Glavni cilj ovog istraživawa je analiza koeficijenta snage plimskih turbina. Ta analiza je rađena na osnovi prikupljenih ulaznoizlaznih parova podataka. Ti podati su aranžirani na osnovi merenje na plimskim turbinama. Adaptivna metodologija mekog računanja je korišćena za estimaciju veza između datih parova podataka. Ta metodologija je kasnije korišćena za predikciju koeficijenta snage plimske turbine na osnovu naučenog znanja od datih parova podataka. U toku procedure merenja tri ulazna parametra i jedan izlaz su korišćeni. Ulazi su odnos brzine vrha turbine, brisna povrpina turbine i vremenski korak. Izlazni parametar je koeficijent snage. Kao metodologija mekog računanja korišćena je adaptivna neuro fazi metdologija odnosno ANFIS. Na kraju su ANFIS rezultati upoređeni sa rezultatima klasičnih neuronskih mreža.

Ključne reči: plimske turbine, koeficijent snage, meko računanje, predikcija

\section{INTRODUCTION}

In the future marine renewable energy has the potential to make significant contribution in energy supplies. Two marine renewable energies are tidal and wave energies. In order to optimize the marine energy power coefficient must be analyzed and predicted as easy as possible and with without implementation of many input parameters. There are several investigations on the tidal turbine power estimation.

In work [1] simulations were performed using $3 \mathrm{D}$ computational fluid dynamical models to predict the power output, torque fluctuations and loading characteristics of three straight-bladed vertical axis tidal turbines where the selection of strut section and bladestrut joint design was found to have a crucial impact on power output. A code was developed in article [2] to predict power extraction capacity for the various number of flapping hydrofoils based on the kinematic and hydrodynamic models and the model can be used as one of initial tools to predict power capacity for obtaining vast concept regarding tidal sites with the flapping foil hydrokinetic turbines. The aim of paper [3] was to better understand the kinetic energy extraction by varying the material modulus of a turbine blade and results were revealed that the 3 bladed rotor displayed maximum hydrodynamic performance as a rigid structure which then decreased as the blade deformed. A numerical model was proposed in article [4] to efficiently compute the power produced by a row of Vertical Axis Water Turbines (VAWTs) deployed in parallel for various water flow conditions. For various purposes, investors, industries, government and academics are looking to identify the best device in terms of cost of energy and performance. However, it is difficult to compare the cost of energy of new devices directly because of uncertainties in the operational and capital costs. It may however be possible to compare the power output of different devices by standardizing the definition of power coefficients. In paper [5] was derived a formula to quantify the power coefficient of different devices.

In this investigation adaptive neuro-fuzzy inference system (ANFIS) [6-15] was applied to predict the tidal turbine power coefficient. ANFIS results are compared with artificial neural network (ANN) results.

\section{METHODOLOGY}

\subsection{Experimental measurement}

Blade is the most crucial part of the turbine. The water velocity of the tidal currents strikes the turbine blades and lead to the rotation of turbine. This converts the kinetic energy of the tidal currents into rotational energy for the generator and eventually into the electricity. The power produced by such turbines is given by 


$$
\mathrm{P}=0.5 \mathrm{C}_{\mathrm{p}} \rho \mathrm{A} \mathrm{V}^{3}
$$

where, $\mathrm{P}(\mathrm{W})$ is the power produced, $\mathrm{C}_{\mathrm{p}}$ (dimensionless) is the coefficient of power, $\mathrm{A}\left(\mathrm{m}^{2}\right)$ is the flow contact and $\mathrm{V}(\mathrm{m} / \mathrm{s})$ is the inlet velocity for the turbine. Table 1 represents the parameters of the turbine studied.

\begin{tabular}{ll}
\hline Parameter & $\begin{array}{l}\text { Description for tidal } \\
\text { turbine }\end{array}$ \\
\hline Hydrofoil & NACA 0025 \\
Number of blades & Three \\
Blade length & $700 \mathrm{~mm}$ \\
Radius of the turbine & $500 \mathrm{~mm}$ \\
Rotational speed & $50 \mathrm{rpm}$ \\
Collapsible entities for each & Three \\
blade & Half of the installed \\
Foldable capacity & size \\
Ratio of scaling & 0.95 \\
\hline
\end{tabular}

Table 1. Parameters of the tidal turbine

In this investigation three parameters are selected as the inputs. Table 2 shows three input and output parameter which are used in this investigation. Output parameter is determined by measurements.

\begin{tabular}{cll}
\hline Inputs & $\begin{array}{l}\text { Parameters } \\
\text { description }\end{array}$ & Symbol \\
\hline input 1 & $\begin{array}{l}\text { TSR } \\
\text { (dimensionless) }\end{array}$ & TSR \\
\hline input 2 & Area $\left(\mathrm{m}^{2}\right)$ & $\mathrm{A}$ \\
\hline input 3 & $\begin{array}{l}\text { Time Step } \\
\text { (seconds) }\end{array}$ & $\mathrm{t}$ \\
\hline output & $\begin{array}{l}\text { Power coefficient } \\
\text { (dimensionless) }\end{array}$ & $\mathrm{CP}$ \\
\hline
\end{tabular}

Table 2. Input and output parameters

\subsection{ANFIS methodology}

Fuzzy inference system is used in the process of the ANFIS training and evaluation. The fuzzy IF-THEN rules of Takagi and Sugeno's class and three inputs for the first-order Sugeno is employed for the purposes of this study. The ANFIS has five layers and each of the layer has specific purpose during training and evaluation procedure. The most important is the select fuzzy membership functions before training procedure of ANFIS model. In this study bell-shaped membership functions are used since these functions are capable for establishing of relationships between nonlinet data.

To assess the ANFIS success for prediction of power coefficient, three statistical indicators were used as follows:

1) Root-mean-square error (RMSE)

$$
R M S E=\sqrt{\frac{\sum_{i=1}^{n}\left(P_{i}-O_{i}\right)^{2}}{n}},
$$

2) Coefficient of determination $\left(\mathrm{R}^{2}\right)$

$\mathrm{R}^{2}=\frac{\left[\sum_{\mathrm{i}=1}^{\mathrm{n}}\left(\mathrm{O}_{\mathrm{i}}-\overline{\mathrm{O}_{\mathrm{i}}}\right) \cdot\left(\mathrm{P}_{\mathrm{i}}-\overline{\mathrm{P}_{\mathrm{i}}}\right)\right]^{2}}{\sum_{\mathrm{i}=1}^{\mathrm{n}}\left(\mathrm{O}_{\mathrm{i}}-\overline{\mathrm{O}_{\mathrm{i}}}\right) \cdot \sum_{\mathrm{i}=1}^{\mathrm{n}}\left(\mathrm{P}_{\mathrm{i}}-\overline{\mathrm{P}_{\mathrm{i}}}\right)}$

3) Pearson correlation coefficient (r)

$$
r=\frac{n\left(\sum_{i=1}^{n} O_{i} \cdot P_{i}\right)-\left(\sum_{i=1}^{n} O_{i}\right) \cdot\left(\sum_{i=1}^{n} P_{i}\right)}{\sqrt{\left(n \sum_{i=1}^{n} O_{i}^{2}-\left(\sum_{i=1}^{n} O_{i}\right)^{2}\right) \cdot\left(n \sum_{i=1}^{n} P_{i}^{2}-\left(\sum_{i=1}^{n} P_{i}\right)^{2}\right)}}
$$

where $P_{i}$ and $O_{i}$ are experimental and forecast values, respectively, and $n$ is the total number of data.

\section{RESULTS}

Figure 1 shows scatter plots of prediction of tidal turbine power coefficient with ANFIS and ANN methodologies. As can be noted from the figures the ANFIS methodology gives better prediction accuracy than ANN.

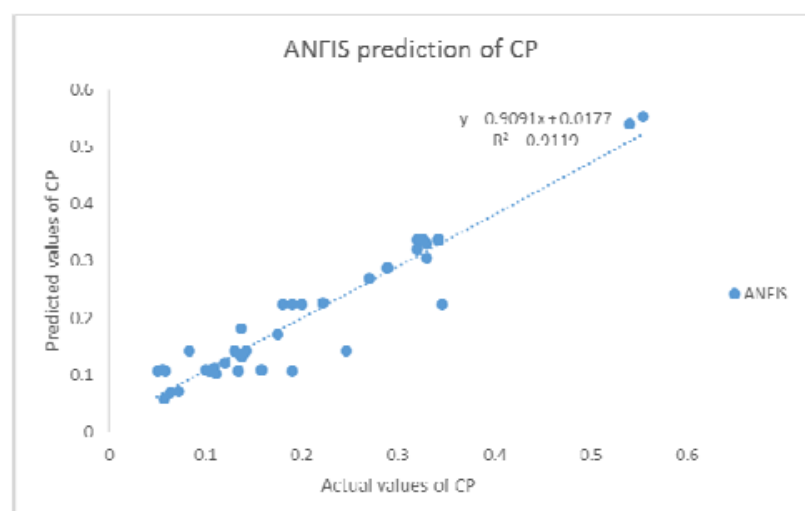

(a)

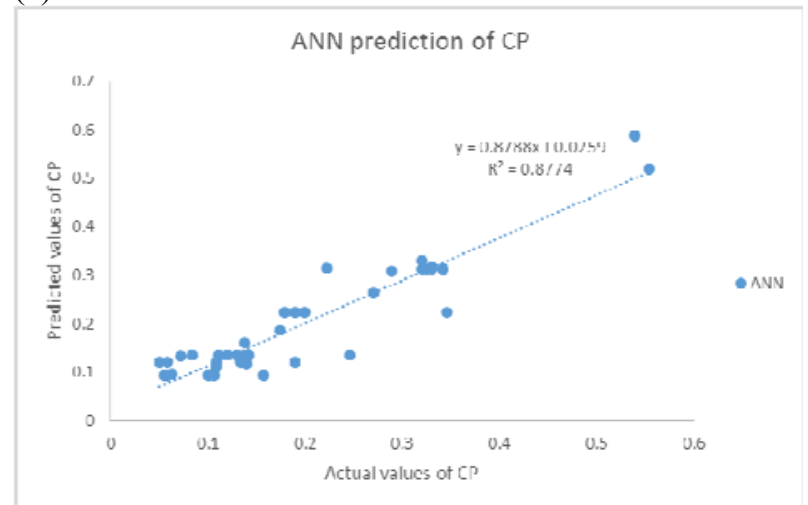

(b)

Fig. 1. Scatter plots for prediction of tidal turbine power coefficient with (a) ANFIS and (b) ANN methodology

The graph of the model for the ANFIS input-output (decision) surface for prediction of the tidal turbine power coefficient is a monotonic non-linear surface as shown in Figure 2. The figures below also shows the response of ANFIS model for the varying selected input parameters. 


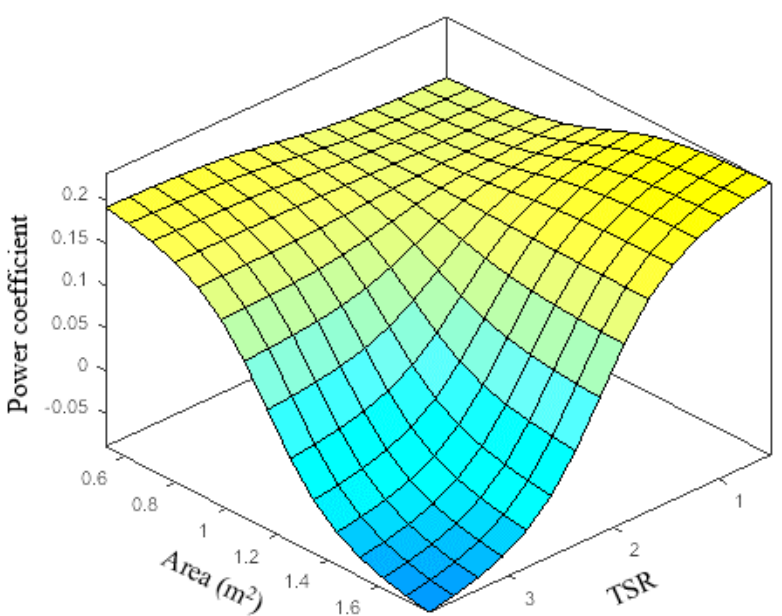

(a)

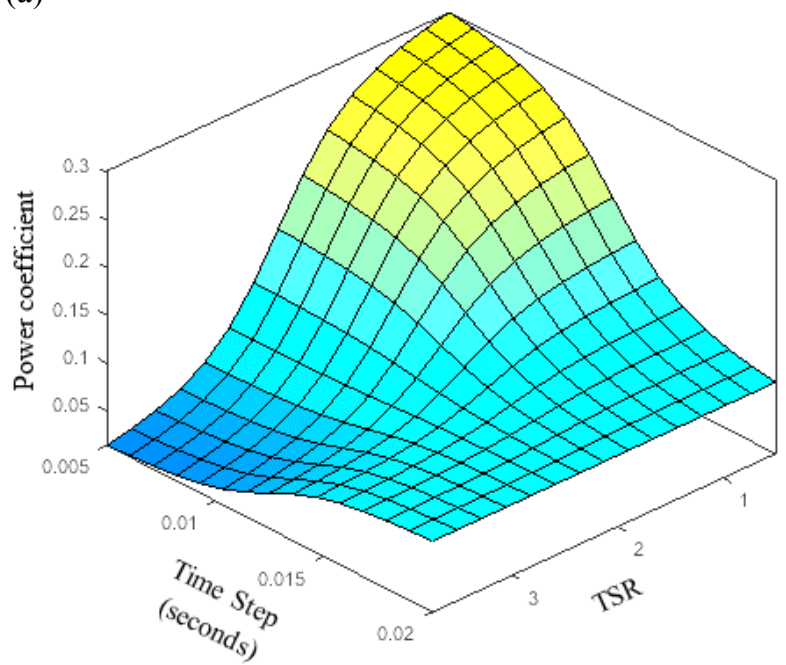

(b)

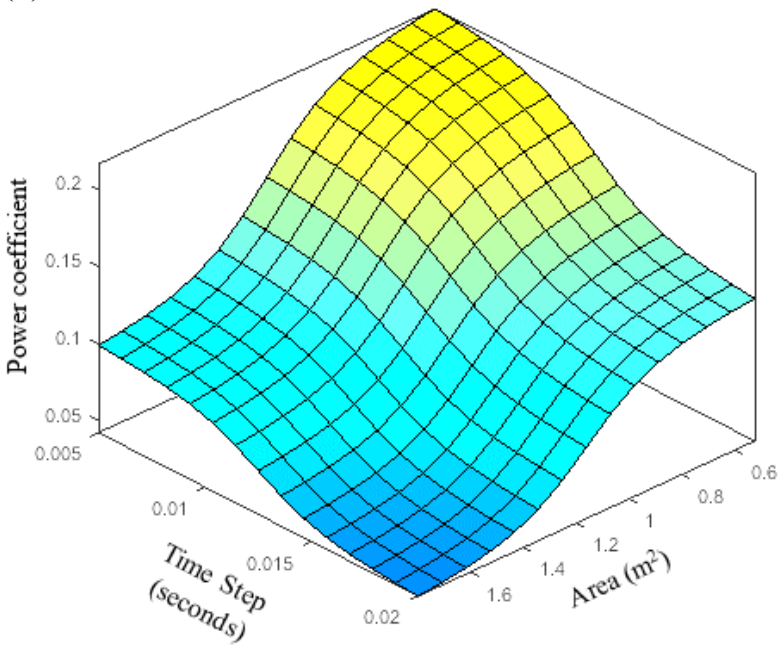

(c)

Fig. 2. ANFIS relationships between inputs and output

Table 3 summarize the prediction accuracy results by ANFIS and ANN methodology.

\begin{tabular}{|c|c|c|}
\hline & ANFIS & ANN \\
\hline $\mathrm{r}$ & 0.95 & 0.93 \\
\hline $\mathrm{R}^{2}$ & 0.91 & 0.87 \\
\hline RMSE & 0.03 & 0.04 \\
\hline
\end{tabular}

Table 3. Statistical results for prediction of tidal turbine power coefficient

\section{CONCLUSION}

In this study was performed an approach for prediction of power coefficient of tidal turbine based on several input parameters. Adaptive soft computing methdology was applied. The methdology was trained by input and output data pairs which are collected during measurement procedure. Based on the results one can conlude that the methodology coud be used effictivelly for tidal turbines' performances prediction.

\section{REFERENCES}

[1] Marsh, P., Ranmuthugala, D., Penesis, I., \& Thomas, G., Three-dimensional numerical simulations of straight-bladed vertical axis tidal turbines investigating power output, torque ripple and mounting forces. Renewable Energy 83 (2015) 67-77.

[2] Karbasian, H. R., Esfahani, J. A., \& Barati, E., Simulation of power extraction from tidal currents by flapping foil hydrokinetic turbines in tandem formation. Renewable Energy 81 (2015) 816-824.

[3] Morris, C. E., O'Doherty, D. M., O'Doherty, T., \& Mason-Jones, A., Kinetic energy extraction of a tidal stream turbine and its sensitivity to structural stiffness attenuation. Renewable Energy 88 (2016) 30-39.

[4] Dominguez, F., Achard, J. L., Zanette, J., \& Corre, C., Fast power output prediction for a single row of ducted cross-flow water turbines using a BEMRANS approach. Renewable Energy 89 (2016) 658-670.

[5] Li, Y., On the definition of the power coefficient of tidal current turbines and efficiency of tidal current turbine farms. Renewable Energy 68 (2014) 868-875.

[6] Mohandes, M., Rehman, S., \& Rahman, S. M., Estimation of wind speed profile using adaptive neuro-fuzzy inference system (ANFIS). Applied Energy 88(11) (2011) 4024-4032.

[7] Ata, R., \& Koçyigit, Y., An adaptive neuro-fuzzy inference system approach for prediction of tip speed ratio in wind turbines. Expert Systems with Applications 37(7) (2010) 5454-5460.

[8] Jang, J. S., ANFIS: adaptive-network-based fuzzy inference system. IEEE transactions on systems, man, and cybernetics 23(3) (1993) 665-685.

[9] Salahshoor, K., Kordestani, M., \& Khoshro, M. S., Fault detection and diagnosis of an industrial steam turbine using fusion of SVM (support vector machine) and ANFIS (adaptive neuro-fuzzy inference system) classifiers. Energy 35(12) (2010) 5472-5482.

[10] Boyacioglu, M. A., \& Avci, D., An adaptive network-based fuzzy inference system (ANFIS) for the prediction of stock market return: the case of the Istanbul stock exchange. Expert Systems with Applications 37(12) (2010) 7908-7912.

[11] Singh, R., Kainthola, A., \& Singh, T. N., Estimation of elastic constant of rocks using an ANFIS approach. Applied Soft Computing 12(1) (2012) 40-45. 
[12] Buragohain, M., \& Mahanta, C., A novel approach for ANFIS modelling based on full factorial design. Applied soft computing 8(1) (2008) 609625.

[13] Khuntia, S. R., \& Panda, S., Simulation study for automatic generation control of a multi-area power system by ANFIS approach. Applied soft computing 12(1) (2012) 333-341.

[14] Chen, M. Y., A hybrid ANFIS model for business failure prediction utilizing particle swarm optimization and subtractive clustering. Information Sciences 220 (2013)180195.

[15] Azamathulla, H. M., Ghani, A. A., \& Fei, S. Y., ANFIS-based approach for predicting sediment transport in clean sewer. Applied Soft Computing 12(3) (2012)1227-1230.

Authors: Professor Srđaj Jović PhD, Assoc. Professor Aleksandar Radović PhD, University of Priština, Faculty of Technical Sciences in Kosovska Mitrovica, Kneza Milosa 7, 38220 Kosovska Mitrovica, Serbia.

E-mail: tjaki@yahoo.com srdjanjovic2016@hotmail.com 